\title{
A Conceptual Framework for the Adoption of E- Government in Indonesia
}

\author{
Alvedi Sabani \\ School of Business IT and Logistics \\ RMIT University \\ Melbourne, Australia \\ Email: alvedi.sabani@rmit.edu.au

\section{Hepu Deng} \\ School of Business IT and Logistics \\ RMIT University \\ Melbourne, Australia \\ Email: hepu.deng@rmit.edu.au
}

\section{Vinh Thai}

School of Business IT and Logistics

RMIT University

Melbourne, Australia

Email: vinh.thai@rmit.edu.au

\begin{abstract}
The rapid development of e-government across the world has opened the discussion on how governments can improve citizens' adoption of their online public services. As a result, the adoption of e-government has become a fundamental issue that needs to be adequately addressed. This paper presents a conceptual framework for examining the adoption of e-government from the perspective of citizens. Through semi-structured interviews conducted in Indonesia, the conceptual framework was validated using thematic analysis, which indicates that performance expectancy, effort expectancy and social influence are interrelated critical factors for the adoption of e-government. In terms of academic contribution, this research provides a better understanding of the critical factors for the adoption of egovernment from the perspective of citizens. With regards to practical implications, this research provides the Indonesian government and public organisations with relevant suggestions on how the adoption of e-government can be improved.
\end{abstract}

\section{Keywords}

E-Government, Adoption, Framework, Critical Factors, Indonesia. 


\section{Introduction}

Electronic government (e-government) is about the use of information and communication technologies (ICT) for improving the delivery of public services to citizens and businesses (Mirchandani et al. 2008). It can be approached from different perspectives. Nam (2014), for example, considers e-government as the delivery of public services through the adoption of digital technologies. Hwang and Syamsuddin (2008) perceive e-government as a way of improving communication between governments and citizens. Meanwhile, Pudjianto et al. (2011) view e-government as a process of enhancing the relationship between governments and their stakeholders including citizens and businesses.

There are various benefits from the development of e-government. For example, it enables seamless two-way communications between governments, citizens, and businesses (Susanto and Goodwin 2013). E-Government improves the quality of public service delivery (Nam 2014) and the transparency of public decision making (Deng et al. 2018), while encouraging citizens' involvement in the public administration (Heeks and Bailur 2007). It also enhances information sharing between government institutions (Puspitasari and Ishii 2016). Besides, the development of e-government streamlines processes in public organisations, therefore improving their efficiency and effectiveness (Debjani et al. 2012). As a result, numerous countries have introduced various initiatives for the development of egovernment (United Nations 2016).

Like many other countries, the government of Indonesia recognises the importance of e-government in making public services more accessible and transparent to the public. In 2001, the government officially introduced the 'e-Indonesia' initiative for facilitating the development of e-government (Republik Indonesia 2014). The government has committed to spending US $\$ 6.78$ billion for egovernment development from 2014 to 2019 (Republik Indonesia 2014). With the implementation of such an initiative, e-government in Indonesia has been developed progressively (United Nations 2016). As a result, Indonesia National Single Window is established, Indonesia Online Immigration Service is introduced, and the National Online Taxation system is developed (Obi and Naoko 2016).

Despite the rapid development of e-government in Indonesia, the adoption of e-government is still far from satisfactory (Deden et al. 2017). The slow adoption of e-government in Indonesia has been widely acknowledged. Maslihatin (2016), for example, find that the average citizen satisfaction index for egovernment across the country is poor. Prahono and Elidjen (2015) show that there are only $15.6 \%$ of e-government services in Indonesia that are fully accessible and work properly. Puspitasari and Ishii (2016) discover that most e-government services in Indonesia are only accessible from computers whereas mobile phones are the preferred communication channel. All these studies show that the adoption of e-government in the country is ineffective.

This study, therefore, proposes a conceptual framework for examining the adoption of e-government in Indonesia from the perspective of citizens. Specifically, this study aims to examine the key factors that influence citizens on their decisions to adopt e-government. To fulfil this aim, the research question for this study is formulated as follows: "what are the key factors that influence e-government adoption in Indonesia?". Such a study can help the government of Indonesia to better plan their egovernment initiatives. Moreover, as several other developing countries are within the comparable stages of e-government development (United Nations 2016), findings from this research in the context of Indonesia might provide a useful reference for them.

\section{E-Government Adoption}

The adoption of e-government generally refers to the intention of citizens to engage in e-government for accessing public services (Mirchandani et al. 2008). Research in this area mainly focuses on the awareness, motivation, and trust of citizens to adopt e-government (Kurfalı et al. 2017). Such research becomes vital given the potential of e-government to reduce costs and improve public service delivery compared with the traditional paper-based services (Karunasena and Deng 2012).

Numerous studies have been conducted for better understanding the adoption of e-government from different perspectives in the literature. Susanto and Goodwin (2013) for example, highlight the importance of having multiple access platforms to support the adoption of e-government. Bertot et al. (2010) study the effect of transparency on the adoption of e-government. Meanwhile, Mirchandani et al. (2008) find that citizens of closely related countries have a very different expectation of their egovernment, which means every country needs a specific e-government adoption strategy. 
These studies have shown their merits in investigating the adoption of e-government from different perspectives. None of these studies, however, have made any further attempt to fully examine the critical factors which may influence citizens' decision to adopt e-government, especially in the context of developing countries such as Indonesia. Furthermore, most studies mainly focus on the performance aspect of e-government, whereas the social influence factor in adopting e-government is often completely neglected. Therefore, this research would be essential in developing more socially acceptable e-government.

Indonesia is a Southeast Asian nation made up of thousands of volcanic islands. It is one of the biggest developing countries with over 257 million citizens. Internet penetration has reached over $40 \%$ of the total population (Statista 2018). Due to these facts, the government of Indonesia believes that egovernment is the most suitable platform to serve the large numbers of citizens distributed in the archipelagic country (Republik Indonesia 2014).

E-Government is being developed rapidly in Indonesia. The 'e-Indonesia' initiative was officially introduced by the Presidential Order No 6/2001. This initiative acts as a backbone of the current egovernment strategy under the supervision of the Ministry of Communication and Information Technology. Following the implementation of the initiative, the government of Indonesia provides a various range of e-government services including Indonesia National Single Window to take care of export and import activities, Indonesia Online Immigration Service to manage visa and passport applications, and National Online Taxation to handle tax number registration and mandatory tax information submission (Obi and Naoko 2016; Republik Indonesia 2014).

The adoption of the above e-government services, however, is still low (Prahono and Elidjen 2015). This is reflected by the world's e-government ranking, as Indonesia has continuously fallen in their position for the past five consecutive years (United Nations 2016). The current study on the critical factors which may influence citizens' adoption of e-government in Indonesia is therefore needed.

\section{Theoretical Foundation and Conceptual Framework}

This research adopts the Unified Theory of Acceptance and Use of Technology (UTAUT) model which examines the user's intention in the adoption of technologies (Venkatesh et al. 2003). With the use of this model, three relevant dimensions including performance expectancy, effort expectancy, and social influence are identified. Performance expectancy is described as the degree to which an individual believes that adopting e-government will result in better public service performance. Effort expectancy is referred to the degree of ease in using e-government. Social influence is defined as the degree to which individuals perceive the importance of others' perceptions on the adoption of e-government.

The UTAUT model is one of the most widely used theoretical lenses for investigating the adoption of specific technologies due to its simplicity, consistency and robustness (Williams et al. 2015). It has been adopted in several e-government adoption studies across the world. Among these, for example, Rana et al. (2017) review the indirect impact of anxiety in the adoption of e-government in India. Kurfalı et al. (2017), meanwhile, investigate the role of trust in citizens' decision to adopt egovernment in Turkey. These studies show that the UTAUT model is appropriate for examining the adoption of e-government from different perspectives. This study, therefore, also adopts the UTAUT model for investigating the adoption of e-government from the perspective of Indonesian citizens.

It is hypothesised, as illustrated in the conceptual framework (Figure 1), that the intention to adopt egovernment is influenced by performance expectancy, effort expectancy, and social influence.

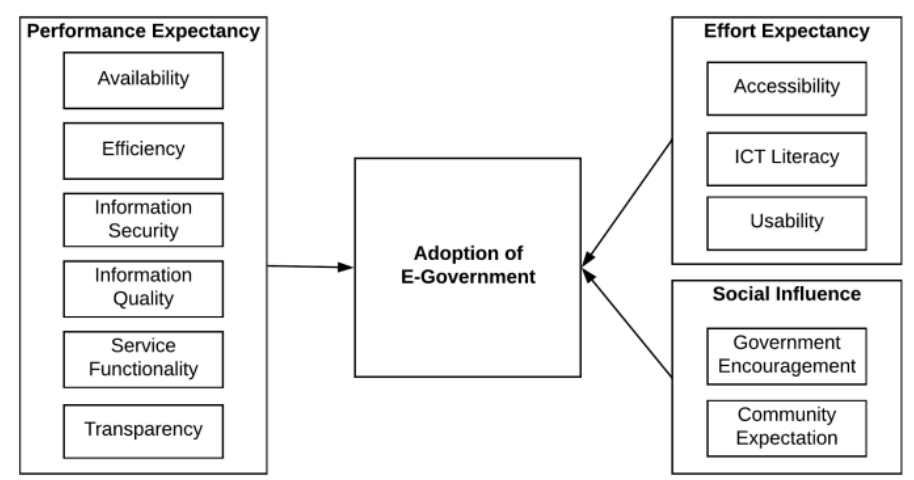

Figure 1: Conceptual Framework 


\section{Performance Expectancy}

Performance expectancy is about the degree to which citizens believes that adopting e-government would result in better public service performance (Venkatesh et al. 2003), measured by their perception of whether the adoption of e-government would be beneficial to them. Performance expectancy is expected to significantly influence the intention to adopt e-government (Kurfalı et al. 2017). Table 1 presents an overview of the measurement variables and indicators for performance expectancy.

\begin{tabular}{|c|c|c|c|c|}
\hline Variables & & Indicators & Definition & References \\
\hline \multicolumn{5}{|c|}{ Performance Expectancy } \\
\hline $\begin{array}{l}\text { Availability is } \\
\text { about the state of e- } \\
\text { government being } \\
\text { available. }\end{array}$ & $\begin{array}{l}\text { (a) } \\
\text { (b) }\end{array}$ & $\begin{array}{l}\text { System availability. } \\
\text { Information } \\
\text { availability. } \\
\text { Service availability. }\end{array}$ & $\begin{array}{l}\text { (a) The availability of e-government system (e.g. } \\
\text { online medicare). } \\
\text { (b) The obtainability of e-government information } \\
\text { (e.g. information on how to contact medicare } \\
\text { office). } \\
\text { (c) The availability of e-government services (e.g. } \\
\text { online medicare claim submission). }\end{array}$ & $\begin{array}{l}\text { Mirchandani et } \\
\text { al. (2008), and } \\
\text { Papadomichelaki } \\
\text { and Mentzas } \\
\text { (2012). }\end{array}$ \\
\hline $\begin{array}{l}\text { Efficiency is about } \\
\text { the ability to } \\
\text { accomplish a certain } \\
\text { task through the use } \\
\text { of e-government } \\
\text { with a lesser } \\
\text { expenditure of cost, } \\
\text { time and effort. }\end{array}$ & $\begin{array}{l}\text { (a) } \\
\text { (b) } \\
\text { (c) }\end{array}$ & $\begin{array}{l}\text { Process simplicity. } \\
\text { Process timeliness. } \\
\text { Process efficiency. }\end{array}$ & $\begin{array}{l}\text { (a) The process of obtaining information and services } \\
\text { from e-government is easily understood. } \\
\text { (b) The process of obtaining information and services } \\
\text { from e-government is done faster than the } \\
\text { traditional approach. } \\
\text { (c) The process of obtaining information and services } \\
\text { from e-government is less expensive than the } \\
\text { traditional approach. }\end{array}$ & 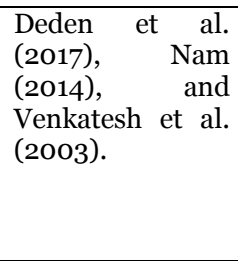 \\
\hline $\begin{array}{l}\text { Information } \\
\text { security is about } \\
\text { the protection of } \\
\text { information from } \\
\text { unauthorized } \\
\text { access, by ensuring } \\
\text { that information is } \\
\text { only accessible to } \\
\text { the right users. }\end{array}$ & $\begin{array}{l}\text { (a) } \\
\text { (b) } \\
\text { (c) } \\
\text { (d) } \\
\text { (e) } \\
\text { (f) }\end{array}$ & $\begin{array}{l}\text { Availability of law. } \\
\text { Organisation } \\
\text { compliance. } \\
\text { Perceived risks. } \\
\text { Information } \\
\text { security awareness. } \\
\text { Trust in information } \\
\text { security. } \\
\text { Confidence in } \\
\text { submitting } \\
\text { credentials. }\end{array}$ & $\begin{array}{l}\text { (a) The existence of security policies in relation to e- } \\
\text { government. } \\
\text { (b) The implementation of policies for securing the } \\
\text { information in e-government. } \\
\text { (c) The uncertainty a user has when using e- } \\
\text { government. } \\
\text { (d) The degree of awareness of citizens to security } \\
\text { policies in e-government. } \\
\text { (e) The degree of trust from citizens to the security of } \\
\text { e-government. } \\
\text { (f) The degree of willingness of citizens to submit } \\
\text { sensitive information to e-government. }\end{array}$ & $\begin{array}{l}\text { AlKalbani et al. } \\
\text { (2017), Debjani } \\
\text { et al. (2012), and } \\
\text { Posthumus and } \\
\text { Von Solms } \\
\text { (2004). }\end{array}$ \\
\hline $\begin{array}{l}\text { Information } \\
\text { quality refers to } \\
\text { the value of the } \\
\text { information } \\
\text { provided by e- } \\
\text { government. }\end{array}$ & $\begin{array}{l}\text { (a) } \\
\text { (b) } \\
\text { (c) } \\
\text { (d) }\end{array}$ & $\begin{array}{l}\text { Information } \\
\text { accuracy. } \\
\text { Information } \\
\text { relevancy. } \\
\text { Information } \\
\text { promptness. } \\
\text { Information } \\
\text { understandability. }\end{array}$ & $\begin{array}{l}\text { (a) The degree of errors in the information. } \\
\text { (b) The degree of match between the information } \\
\text { provided and the information requested. } \\
\text { (c) The measurement of whether the information is } \\
\text { provided at the right time. } \\
\text { (d) The quality of comprehensible information. }\end{array}$ & $\begin{array}{l}\text { Papadomichelaki } \\
\text { and Mentzas } \\
\text { (2012), and } \\
\text { Wangpipatwong } \\
\text { et al.(2009). }\end{array}$ \\
\hline $\begin{array}{l}\text { Service } \\
\text { functionality } \\
\text { refers to the degree } \\
\text { of usefulness } \\
\text { between the services } \\
\text { provided and the } \\
\text { services required. }\end{array}$ & $\begin{array}{l}\text { (a) } \\
\text { (b) } \\
\text { (c) }\end{array}$ & $\begin{array}{l}\text { Service reliability. } \\
\text { Service usability. } \\
\text { Fitness for purpose. }\end{array}$ & $\begin{array}{l}\text { (a) The quality of e-government services being } \\
\text { consistent. } \\
\text { (b) The extent of e-government services in fulfilling } \\
\text { the citizens' requirements. } \\
\text { (c) The extent of e-government services works as } \\
\text { expected. }\end{array}$ & $\begin{array}{lrr}\text { Deden } & \text { et } & \text { al. } \\
(2017), & \text { Idris } \\
(2016), & \text { and } \\
\text { Yasar } & \text { and } \\
\text { Giovanni } & (2007) .\end{array}$ \\
\hline $\begin{array}{l}\text { Transparency } \\
\text { refers to the quality } \\
\text { of being open or } \\
\text { transparent. }\end{array}$ & $\begin{array}{l}\text { (a) } \\
\text { (b) } \\
\text { (c) }\end{array}$ & $\begin{array}{l}\text { Information } \\
\text { transparency. } \\
\text { Process } \\
\text { transparency. } \\
\text { Public participation. }\end{array}$ & $\begin{array}{l}\text { (a) The availability of information in e-government } \\
\text { including the contact information of public } \\
\text { officials, and the timely information about policies, } \\
\text { laws and regulations. } \\
\text { (b) The availability of clear procedures in using e- } \\
\text { government. } \\
\text { (c) The capability of citizens to be involved in public } \\
\text { decision-making through the use of e-government. }\end{array}$ & 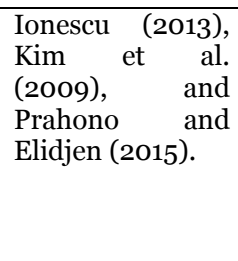 \\
\hline
\end{tabular}

Table 1. Measurement Variables and Indicators for Performance Expectancy

\section{Effort Expectancy}

Effort expectancy is referred to as the degree of ease in using new technologies (Venkatesh et al. 2003). It is recognised to influence the intention to adopt e-government (Williams et al. 2015). Effort expectancy is often measured by the degree of ease associated with learning the technology (Venkatesh et al. 2003). In the current study, effort expectancy is employed to examine if citizens perceive that the benefits of adopting e-government outweigh the efforts of learning the system. Table 2 presents an overview of the measurement variables and indicators for effort expectancy. 


\begin{tabular}{|c|c|c|c|}
\hline Variables & Indicators & Definition & References \\
\hline \multicolumn{4}{|c|}{ Effort Expectancy } \\
\hline $\begin{array}{lll}\text { Accessibility is } & \text { (a) } \\
\text { about the quality } & \text { (b) } \\
\text { of being able to } & \\
\text { reach } & \text { e- } & \text { (c) } \\
\text { government. } & & \text { (d) }\end{array}$ & $\begin{array}{l}\text { Access easiness. } \\
\text { Availability of ICT } \\
\text { devices. } \\
\text { Availability of } \\
\text { internet. } \\
\text { Availability of } \\
\text { multiple platforms } \\
\text { Availability of access } \\
\text { points. }\end{array}$ & $\begin{array}{l}\text { (a) The quality of being easy to access e-government } \\
\text { services and information. } \\
\text { (b) The level of effort that the individual must take to } \\
\text { access ICT devices. } \\
\text { (c) The level of effort that the individual must take to } \\
\text { access internet. } \\
\text { (d) The ability to access e-government from multiple } \\
\text { devices (e.g. personal computers and mobile phones). } \\
\text { (e) The ability to access e-government from public places. }\end{array}$ & $\begin{array}{l}\text { Ahmed and } \\
\text { Shirley (2014), } \\
\text { Idris (2016), } \\
\text { and } \\
\text { Puspitasari } \\
\text { and Ishii } \\
(2016) \text {. }\end{array}$ \\
\hline $\begin{array}{l}\text { ICT Literacy is } \\
\text { about the ability } \\
\text { of individuals to } \\
\text { (c) } \\
\text { the use of ICT } \\
\text { devices at an } \\
\text { adequate level to } \\
\text { perform a certain } \\
\text { task. }\end{array}$ & $\begin{array}{l}\text { ICT self-efficacy. } \\
\text { ICT exposure. } \\
\text { Internet self-efficacy. } \\
\text { Internet exposure. }\end{array}$ & $\begin{array}{l}\text { (a) The degree of individuals' beliefs about their abilities } \\
\text { to use ICT devices. } \\
\text { (b) The extent of experience of individuals to the use of } \\
\text { ICT devices. } \\
\text { (c) The degree of individuals' beliefs about their abilities } \\
\text { to use internet. } \\
\text { (d) The extent of experience of individuals to the use of } \\
\text { internet. }\end{array}$ & $\begin{array}{l}\text { Maslihatin } \\
(2016), \\
\text { Puspitasari } \\
\text { and Ishii } \\
\text { (2016), and } \\
\text { van Deursen } \\
\text { and van Dijk } \\
(2011) \text {. }\end{array}$ \\
\hline $\begin{array}{lll}\text { Usability is } & \text { (a) } \\
\text { about is the level } & \text { (b) } \\
\text { of effort that } & \text { (c) } \\
\text { citizens must } & \text { (d) } \\
\text { make to learn and } & \\
\text { use e-government. }\end{array}$ & $\begin{array}{l}\text { User friendliness. } \\
\text { User intuitiveness. } \\
\text { System navigation. } \\
\text { Learnability. }\end{array}$ & $\begin{array}{l}\text { (a) The quality of e-government systems being easy to } \\
\text { use. } \\
\text { (b) The quality of e-government systems being self- } \\
\text { explanatory. } \\
\text { (c) The quality of e-government systems being easy to } \\
\text { navigate. } \\
\text { (d) The quality of e-government systems being easy to } \\
\text { learn. }\end{array}$ & \begin{tabular}{l}
\multicolumn{2}{l}{ Puspitasari } \\
and \\
$(2016), \quad$ and \\
Susanto and \\
Goodwin \\
(2013).
\end{tabular} \\
\hline
\end{tabular}

Table 2. Measurement Variables and Indicators for Effort Expectancy

\section{Social Influence}

Social influence is the external dimension that affects an individual's decision to adopt new technologies (Venkatesh et al. 2003). This dimension has not been popularly examined in the context of e-government adoption studies. Table 3 presents an overview of the measurement variables and indicators for social influence.

\begin{tabular}{|c|c|c|c|}
\hline Variables & Indicators & Definition & References \\
\hline \multicolumn{4}{|c|}{ Social Influence } \\
\hline $\begin{array}{l}\text { Government } \\
\text { Encouragement } \\
\text { refers to the actions } \\
\text { taken by the } \\
\text { government to } \\
\text { support the } \\
\text { adoption of e- } \\
\text { government. }\end{array}$ & $\begin{array}{l}\text { (a) Awareness support. } \\
\text { (b) Availability of } \\
\text { support centres. } \\
\text { (c) Availability of } \\
\text { financial incentive. } \\
\text { (d) Availability of ICT } \\
\text { training. }\end{array}$ & $\begin{array}{l}\text { (a) The level of support from the government to maintain } \\
\text { the timely information to the presence of e- } \\
\text { government. } \\
\text { (b) The level of support from the government to assist } \\
\text { citizens in using e-government (e.g. phone and web } \\
\text { support centres). } \\
\text { (c) The availability of financial benefits provided by the } \\
\text { government to citizens for adopting e-government } \\
\text { systems. } \\
\text { (d) The availability of ICT training provided by the } \\
\text { government to citizens. }\end{array}$ & $\begin{array}{l}\text { Furuholt and } \\
\text { Wahid } \\
\text { (2008), } \\
\text { Hwang and } \\
\text { Syamsuddin } \\
\text { (2008), and } \\
\text { Nurdin et al. } \\
\text { (2012). }\end{array}$ \\
\hline $\begin{array}{l}\text { Community } \\
\text { Expectation is } \\
\text { defined as } \\
\text { compression by a } \\
\text { person's proximity } \\
\text { to take certain } \\
\text { actions or adopt } \\
\text { certain values. }\end{array}$ & 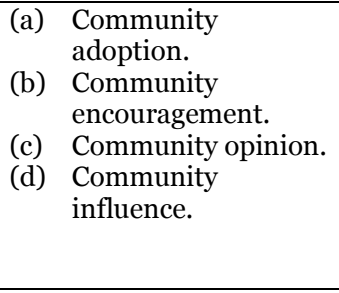 & $\begin{array}{l}\text { (a) The level of e-government acceptance from } \\
\text { individuals' community. } \\
\text { (b) The level of encouragement from individuals' } \\
\text { community to adopt e-government. } \\
\text { (c) The belief of individuals' community in the e- } \\
\text { government system. } \\
\text { (d) The degree to which individuals perceive that the } \\
\text { importance of others' perceptions on the decision to } \\
\text { adopt of e-government. }\end{array}$ & $\begin{array}{l}\text { Deden et al. } \\
\text { (2017), Kurfalı } \\
\text { et al. (2017), } \\
\text { Rana et al. } \\
\text { (2017), and } \\
\text { Voutinioti } \\
\text { (2013). }\end{array}$ \\
\hline
\end{tabular}

Table 3. Measurement Variables and Indicators for Social Influence

\section{Research Methodology}

This study takes the qualitative approach, using in-depth interviews, to empirically validate the proposed conceptual framework for the adoption of e-government in Indonesia from the perspective of citizens. The interview questions were developed based on a comprehensive review of the related literature. Such questions are divided into three parts. The first part focuses on the demographic information of the participant. The second part includes general questions about the experience and motivation of participants in their adoption of e-government. The third part consists of specific questions on the critical factors for the adoption of e-government from the perspective of citizens. The 
interview questions were pre-tested with the help of academics, higher degree research scholars, and e-government users.

This research employed purposive and snowball sampling and recruited 15 participants across three provinces in Indonesia, namely Banten, Jakarta, and West Java. The selection criteria include Indonesian citizen of more than 18 years of age and have previously used e-government services. Participants were chosen based on their knowledge and experience in using e-government services. These participants have diverse demographic characteristics as shown in Table 4.

\begin{tabular}{|c|c|c|c|c|c|}
\hline \# & Age Group & Gender & Education & Occupation & Frequency of Using E-Government \\
\hline 1 & $21-30$ & Male & Bachelor Degree & Private Sector Employee & Rarely (once in a year) \\
\hline 2 & $21-30$ & Male & Bachelor Degree & Medical Doctor & Often (once in 3 months) \\
\hline 3 & $21-30$ & Female & Master Degree & Private Sector Employee & Sometimes (once in 6 months) \\
\hline 4 & $31-45$ & Male & Master Degree & Self-Employed & Very often (once in a month) \\
\hline 5 & $21-30$ & Male & Diploma & Self-Employed & Often (once in 3 months) \\
\hline 6 & $21-30$ & Female & Bachelor Degree & Private Sector Employee & Sometimes (once in 6 months) \\
\hline 7 & $21-30$ & Male & High School & Student & Very rarely (less than once in a year) \\
\hline 8 & $21-30$ & Male & Bachelor Degree & Public Sector Employee & Often (once in 3 months) \\
\hline 9 & $46-60$ & Female & Bachelor Degree & Public Sector Employee & Very often (once in a month) \\
\hline 10 & $46-60$ & Male & Master Degree & Academic & Often (once in 3 months) \\
\hline 11 & $21-30$ & Male & Master Degree & Public Sector Employee & Often (once in 3 months) \\
\hline 12 & $21-30$ & Male & Bachelor Degree & Private Sector Employee & Rarely (once in a year) \\
\hline 13 & $31-45$ & Male & Diploma & Private Sector Employee & Rarely (once in a year) \\
\hline 14 & $31-45$ & Female & Bachelor Degree & Private Sector Employee & Sometimes (once in 6 months) \\
\hline 15 & $18-20$ & Female & High School & Private Sector Employee & Very rarely (less than once in a year) \\
\hline
\end{tabular}

Table 4. Profile of Participants

The thematic analysis is utilised in this research, due to its simplicity, less demanding obligation of only a few constraints on the data collection and analysis (Braun and Clarke 2006). The approach is to summarise a large volume of data into meaningful and descriptive themes (Howitt 2013). This method entails several phases. The first phase is familiarising with the transcribed text to get a better understanding of the whole data set. The second phase is the initial coding which involves assigning specific codes to the transcribed text. In this study, codes are created in a deductive manner by reviewing the data with specific classifications based on pre-existing theoretical concerns (Howitt 2013). The third phase involves searching for themes based on the initial coding. Themes are identified by reviewing each code to sort into meaningful clusters (Attride-Stirling 2001; Howitt 2013). The fourth phase is to review the themes by splitting certain themes into two or more themes, and converging overlapping themes (Braun and Clarke 2006). The fifth phase is to define and name themes based on the essences of what each theme is about (Braun and Clarke 2006). The sixth phase is to produce the report by developing thematic networks that show the important themes at multiple levels and their relationships (Attride-Stirling 2001). In short, the thematic analysis uncovers insights, and reveals the similarities and differences between the responses of participants.

\section{Research Findings}

Figure 2 summarises the research findings around the three dimensions identified in the conceptual framework, namely, performance expectancy, effort expectancy, and social influence. Each dimension consists of factors with the level of influence that has been assessed from the thematic analysis.

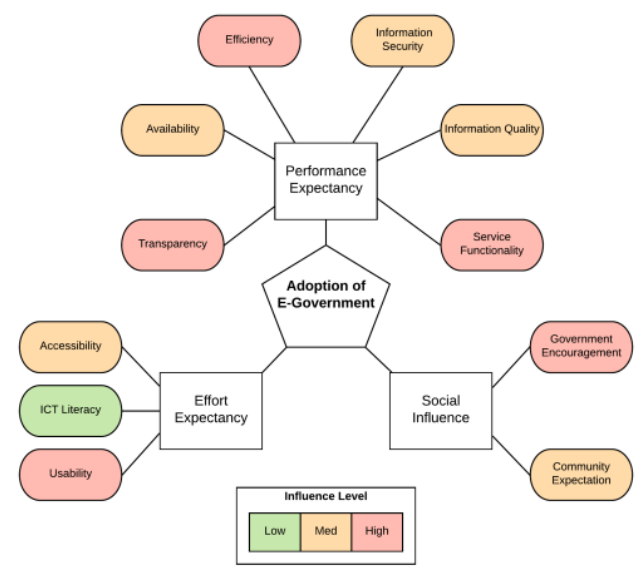

Figure 2: Thematic Research Findings 


\section{Performance Expectancy}

The thematic analysis unanimously confirms that all factors under performance expectancy are influencing the citizens' decision to adopt e-government. Furthermore, eleven out of fifteen interviewees believed that the performance of e-government is the most vital aspect towards the adoption of e-government. It was further indicated that efficiency, service functionality and transparency are the three most influencing factors, followed by availability, information security, and information quality.

Efficiency is about the ability to accomplish a specific task through the use of e-government with a lesser expenditure of cost, time and effort (Deden et al. 2017). It is perceived to be the most influencing factor for nine interviewees to adopt e-government. Interviewees believe that e-government has enabled them to access public services without time and space constraints, as explained by one interviewee as follows:

"Efficiency is the main reason why I am using e-government. With e-government, I do not have to take a day off to report my annual tax, as the online service is available $24 / 7$ whereas taxation offices only open on standard working hours."

It is also shown that e-government streamlines public services to become simpler, faster and more cost effective. Citizens can reduce the number of physical visits to government offices by using egovernment services. Interviewees, therefore, believed that e-government saves their time and money, as well as makes their lives easier. Another interviewee explained this as follows:

"E-Government makes it (government-related services) simpler, cheaper and faster, as we do not need to come and waste our time in the long queue. In that regards, it is very efficient."

Service functionality refers to the degree of usefulness between the services provided and the services required (Nam 2014). It can be assessed by measuring the extent that e-government services fulfil the citizens' requirements (Yasar and Giovanni 2007). From the interviews, service functionality is perceived to influence the intention to adopt e-government, in which a bad experience of service functionality can significantly demotivate citizens to adopt e-government. This view is elaborated by an interviewee as follows:

"I have a horrible experience with using e-government. For me, to use e-government again, the system has to be proven working properly; otherwise, I will not touch the system. When I tried to lodge my tax online last year, the server kept crashing, and I had to resubmit all my data as there was no autosave function. It was such a terrible experience. I ended up lodging it manually, which took me a whole day, but at least it got the job done."

Transparency refers to the quality of being open or transparent. It is measured through the availability of information in e-government including the contact information of public officials, the information to government budgets and expenditures, the operational guidelines of e-government, the timely information about policies, laws and regulations. This factor was confirmed to influence the adoption of e-government (Karunasena and Deng 2012), and it was also echoed in this research. This is reflected through the opinion of an interviewee as follows:

"Before the introduction of e-government, it was very difficult to find a clear procedure on how to upgrade my land and building development permits. Now, with this mobile application, I can track the progress of my application and contact the responsible personnel for my query easily."

Availability refers to the extent of e-government systems including services and information being available (Williams et al. 2015), and this factor was also confirmed to influence the adoption of egovernment in the literature. It was found through the thematic analysis of this research that there is a nexus between the perception of citizens on the availability of e-government and government encouragements on public awareness. This shows that there is a need for an integrated one-stop portal to all kind of e-government services, as elaborated by an interviewee in the following:

"I am not quite sure what e-government services are available due to low publicity.... the government should create a one-stop portal for citizens to check and find all kind of egovernment services available."

Information security is about the implementation of policies for securing the information in egovernment (Debjani et al. 2012). It is about the protection of information from unauthorised access, 
by ensuring that information is only accessible to the right users (Posthumus and Von Solms 2004). It is envisaged that issues relating to information security may ruin the trust of citizens in adopting egovernment, as illustrated by an interviewee as follows:

"I have seen a potential misuse due to mishandling of data from the department of education. The department implemented an online database of students from primary to university level to subdue fake certificate issues. When my child was graduating from elementary school, I searched up by his name and school. The system somehow displayed all his details including home address and landline. It was a concern to me, although the department has now fixed it."

It is argued that citizens are concerned about the information security breach, such as those in the above potential misuse of information stored in e-government. Consequently, citizens may hesitate to adopt e-government due to security concerns. Another interviewee, however, counter-arguing that paper-based services might carry similar or even more risks compared to the online counterpart, expressed his view as the following:

"I have no problem with submitting my sensitive information online, as sometimes you have to live with your personal data at risk. For example, if we are talking about the manual submission directly to the office, the file can be misplaced, misused and other problems."

In addition, findings from the interviews highlight the importance of having an official account for information security confidence in using e-government services. An interviewee believed that establishing an official developer account for e-government applications can increase citizens' confidence, and eliminate confusions from third-party applications. This view is illustrated as follows:

"The government should have an official account at App Store, so we know the application is secured and legit."

Last but not least, information quality refers to the value of the information provided by e-government (Wangpipatwong et al. 2009). It can be assessed by measuring the value of the supplied information, based on its accuracy, relevancy, and timeliness. Specifically, accuracy refers to the degree of errors relating to the information provided; relevancy refers to the degree of match between the information provided and the information requested; and timeliness measures if the information is provided at the right time (Wangpipatwong et al. 2009). In this research, the interviews confirmed the importance of information quality and how this factor positively influences the intention to adopt e-government. An interviewee remarked as follows:

"For e-government to be successful, it has to provide up-to-date and accurate information. I have to be able to trust the information I receive from e-government before I want to use the system."

It was also revealed that having access to the latest and accurate information provided in an understandable manner increases citizens' confidence in adopting e-government as it could affect the level of trust, which is crucial to the adoption. An interviewee elaborated this as follows:

"When I browse a government website, the first thing I check is whether they have a new post or announcement. If there is no recent update, I am very sceptical of using the service or believing that the information provided is still relevant."

\section{Effort Expectancy}

Effort expectancy is widely argued and validated in the literature as one of the three dimensions having a significant influence on the adoption of e-government. In this research, it was specifically evidenced through thematic analysis that usability is the most influencing factors, followed by accessibility and ICT literacy.

In the current study, usability is about the quality of being easy to use e-government (Debjani et al. 2012). It can be assessed by measuring the level of effort that citizens must make to access egovernment. Usability plays a significant role especially in the early stage of e-government adoption as humans by nature often hesitate to adopt a new system (Puspitasari and Ishii 2016). The adoption of e-government is found to be improved when the usability is enhanced (Susanto and Goodwin 2013). A majority of the interviewees further stressed that usability is the most prominent component to support the adoption of e-government, as illustrated by an interviewee as follows: 
"I have seen a few potentially great e-government services without clear information on how to use it, thus I ended up not using the system, which is not good. The government should provide a clear procedure or a video to educate on how to use the particular service. Otherwise, it is a waste of development as no one will use it."

In the context of e-government, accessibility refers to the quality of being able to reach e-government (Idris 2016). This includes the ability to access e-government from multiple devices including personal computers and mobile phones, and public places such as public libraries and government offices. This factor is confirmed to influence the adoption of e-government in this research, in line with what was reported in the literature. It was indicated through thematic analysis that mobile phones are the preferred communication channel for the majority of the interviewees in accessing e-government, as explained by an interviewee as follows:

"Mobile phone is my preferred device to access e-government, as I spend most of the time away from computers."

However, for specific services involving a significant amount of data entry such as online tax lodgement, personal computers are the preferred device. It was also perceived that there is a need for public access at libraries and government offices as indicated by an interviewee in the following:

"The government should provide computers for public use at immigration and taxation offices.”

Meanwhile, ICT literacy, often defined as the ability to use ICT peripherals at an adequate level to perform a specific task (van Deursen and van Dijk 2011), has also been identified as one of the influencing factors for e-government adoption. Despite the fact that Indonesia is a country with the high use of internet and technology, there are still many citizens in the country that lack computer literacy (Furuholt and Wahid 2008) and may not be able to fully access and utilise e-government services. This is demonstrated in a quote by an interviewee as follows:

"I believe the current e-government is designed for intermediate ICT users, whereas it should be designed to cater all kind of people including those who are not literate with ICT."

Nevertheless, it was found through the thematic analysis in this research that ICT literacy is the least influencing factor for the adoption of e-government in Indonesia.

\section{Social Influence}

Apart from performance expectancy and effort expectancy, findings from the current research also establish that social influence also affects the adoption of e-government. Social influence is seen to comprise two factors that stimulate the adoption of e-government, namely, government encouragement, and community expectation. It was revealed through the thematic analysis that government encouragement has a stronger influence than that of community expectation when it comes to e-government adoption in Indonesia.

Government encouragement refers to the actions taken by the government to support the adoption of e-government (Furuholt and Wahid 2008). It can be assessed by measuring the level of effort taken and incentives provided by governments to encourage the citizens to adopt e-government.

Failures in the adoption of e-government are often due to the lack of government encouragement for citizens to adopt e-government (Nurdin et al. 2012). In this research, it was also evidenced through the thematic analysis that government encouragement is a strong factor which influences the adoption of e-government. In this respect, an interviewee shared his opinion about the poor publicity of egovernment services in Indonesia as follows:

"The socialisation of e-government services aside from e-filling for the tax is very poor, how are we supposed to adopt the service if we do not know the existence of them in the first place."

Findings from this research highlight the need for a frequently updated official portal to integrate and showcase all e-government services. The use of social media and mass media channels such as YouTube and TV is also necessary to raise the awareness of the available e-government services. This is demonstrated by an interviewee in the following:

"The government might have provided several e-government services, but the awareness is very low due to the lack of publicity. YouTube and social media advertisement should be utilised to raise awareness." 
Meanwhile, community expectation is defined as the compression by a person's proximity to take specific actions or adopt certain values (Rana et al. 2017). It can be measured by the degree to which an individual perceives the importance of others' opinions on the adoption of e-government. Findings in this research specifically indicate that the influence of family, friends and co-workers has some impact on an individual's intention to adopt a socially acceptable system such as e-government. This is demonstrated by an interviewee who stated as follows:

"I am actively encouraging the use of e-government to my friends and families."

Under these social pressures, individuals are encouraged to recognise the advantage of innovation and embrace the need to adopt e-government to satisfy their needs of public services.

\section{Discussion and Conclusion}

This study makes several significant contributions and has implications for theory building and management practice. From the theoretical perspective, this paper presents a conceptual framework for examining the adoption of e-government from the perspective of Indonesian citizens. The use of the UTAUT model is extended by incorporating variables established from the critical factors that are relevant to the adoption of e-government in developing countries such as Indonesia. Apart from the common belief which focuses predominantly on performance expectancy and effort expectancy for examining the adoption of e-government, findings from this study also suggest that it is necessary to capture the social influence factors, which are in line with the cultural aspect of collectivism which is evidenced in the Indonesian society. This contributes to advancing current understanding of the critical factors which influence the adoption of e-government by emphasising the effect of external factors such as those from the cultural perspective. Meanwhile, in terms of managerial and policy implications, findings from this research provide the government and public organisations in Indonesia with relevant suggestions on how the adoption of e-government can be improved, focusing on the factors which are perceived by citizens as having strong influence on their adoption of egovernment. Such suggestions can lead to the formulation of better strategies and policies for the continuous development of e-government in Indonesia.

Since the framework of this research was only validated by fifteen in-depth interviews, its generalisability remains limited. As a result, future work would be to test this conceptual framework with a large-scale quantitative survey.

\section{References}

Ahmed, I., and Shirley, G. 2014. "A Comparative Analysis of Strategies for E-Government in Developing Countries," Journal of Business Systems, Governance and Ethics (2:3).

AlKalbani, A., Deng, H., Kam, B., and Zhang, X. 2017. "Information Security Compliance in Organizations: An Institutional Perspective," (1:2), p. 104.

Attride-Stirling, J. 2001. "Thematic Networks: An Analytic Tool for Qualitative Research," Qualitative Research (1:3), pp. 385-405.

Bertot, J.C., Jaeger, P.T., and Grimes, J.M. 2010. "Using Icts to Create a Culture of Transparency: EGovernment and Social Media as Openness and Anti-Corruption Tools for Societies," Government Information Quarterly (27:3), pp. 264-271.

Braun, V., and Clarke, V. 2006. "Using Thematic Analysis in Psychology," Qualitative Research in Psychology (3:2), 2006/01/01, pp. 77-101.

Debjani, B., Umesh, G., and Gupta, M.P. 2012. "E-Service Quality Model for Indian Government Portals: Citizens's Perspective," Journal of Enterprise Information Management (25:3), pp. 246-271.

Deden, W., Teddy, S., Mohd Farhan, M.D.F., and Mohamad Aizi, S. 2017. "The Critical Factors Affecting E-Government Adoption in Indonesia: A Conceptual Framework," International Journal on Advanced Science (7:1), pp. 160-167.

Deng, H., Karunasena, K., and $\mathrm{Xu}, \mathrm{W}$. 2018. "Evaluating the Performance of E-Government in Developing Countries," Internet Research (28:1), pp. 169-190.

Furuholt, B., and Wahid, F. 2008. "E- Government Challenges and the Role of Political Leadership in Indonesia: The Case of Sragen." pp. 411-411.

Heeks, R., and Bailur, S. 2007. "Analyzing E-Government Research: Perspectives, Philosophies, Theories, Methods, and Practice," Government Information Quarterly (24:2), pp. 243-265.

Howitt, D.a. 2013. Introduction to Qualitative Methods in Psychology, (Second edition. ed.). Harlow, England: PEARSON. 
Hwang, J., and Syamsuddin, I. 2008. "Failure of E-Government Implementation: A Case Study of South Sulawesi." pp. 952-960.

Idris, S.H.M. 2016. "Significant Factors Determining E-Government Adoption in Selangor, Malaysia," Acta Universitatis Danubius: Oeconomica (12:3), pp. 163-172.

Ionescu, L. 2013. "The Impact That E-Government Can Have on Reducing Corruption and Enhancing Transparency," Economics, Management, and Financial Markets:2), pp. 210-215.

Karunasena, K., and Deng, H. 2012. "Critical Factors for Evaluating the Public Value of E-Government in Sri Lanka," Government Information Quarterly (29), p. 76.

Kim, S., Kim, H.J., and Lee, H. 2009. "An Institutional Analysis of an E-Government System for AntiCorruption: The Case of Open," Government Information Quarterly (26:1), pp. 42-50.

Kurfall, M., Arifoğlu, A., Tokdemir, G., and Paçin, Y. 2017. "Adoption of E-Government Services in Turkey," Computers in Human Behavior (66), pp. 168-178.

Maslihatin, T. 2016. "Balanced Scorecard : Performance Measurement for E-Government," Journal of Theoretical and Applied Information Technology (90:2), pp. 116-123.

Mirchandani, D., Johnson Jr, J., and Joshi, K. 2008. "Perspectives of Citizens Towards E-Government in Thailand and Indonesia: A Multigroup Analysis," Information Systems Frontiers (10:4), pp. 483-497.

Nam, T. 2014. "Determining the Type of E-Government Use," Government Information Quarterly (31:2), pp. 211-220.

Nurdin, N., Stockdale, R., and Scheepers, H. 2012. "Organizational Adaptation to Sustain Information Technology: The Case of E-Government in Developing Countries," Electronic Journal of EGovernment (10:1), pp. 70-83.

Obi, T., and Naoko, I. 2016. "A Decade of World E-Government Rankings." Beaverton: Ringgold Inc.

Papadomichelaki, X., and Mentzas, G. 2012. "E-Govqual: A Multiple-Item Scale for Assessing EGovernment Service Quality," Government Information Quarterly (29), p. 98.

Posthumus, S., and Von Solms, R. 2004. "A Framework for the Governance of Information Security," Computers \&amp; Security (23:8), pp. 638-646.

Prahono, A., and Elidjen, A. 2015. "Evaluating the Role E-Government on Public Administration Reform: Case of Official City Government Websites in Indonesia," Procedia Computer Science (59), pp. 27-33.

Pudjianto, B., Zo, H., Ciganek, A., and Rho, J.J. 2011. "Determinants of E-Government Assimilation in Indonesia: An Empirical Investigation Using Toe Framework," Asia Pasific Journal of Information Systems (21:1).

Puspitasari, L., and Ishii, K. 2016. "Digital Divides and Mobile Internet in Indonesia: Impact of Smartphones," Telematics and Informatics (33:2), pp. 472-483.

Rana, N., Dwivedi, Y., Lal, B., Williams, M., and Clement, M. 2017. "Citizens' Adoption of an Electronic Government System: Towards a Unified View," A Journal of Research and Innovation (19:3), pp. 549-568.

Republik Indonesia. 2014. "Rencana Pitalebar Indonesia 2014 - 2019," K.P.P. Nasional (ed.). Jakarta: Republik Indonesia.

Statista. 2018. "Internet User Penetration in Indonesia from 2015 to 2022," New York.

Susanto, T.D., and Goodwin, R. 2013. "User Acceptance of Sms-Based E- Government Services: Differences between Adopters and Non-Adopters," Government Information Quarterly (30:4), pp. 486-497.

United Nations. 2016. "United Nations E-Government Survey 2016," Department of Economic and Social Affairs, New York.

van Deursen, A., and van Dijk, J. 2011. "Internet Skills and the Digital Divide," New Media and Society (13:6), pp. 893-911.

Venkatesh, V., Morris, M., Davis, G., and Davis, F. 2003. "User Acceptance of Information Technology: Toward a Unified View," MIS Quarterly (27:3), pp. 425-478.

Voutinioti, A. 2013. "Determinants of User Adoption of E-Government Services in Greece and the Role of Citizen Service Centres," Procedia Technology (8), pp. 238-244.

Wangpipatwong, S., Chutimaskul, W., and Papasratorn, B. 2009. "Quality Enhancing the Continued Use of E-Government Web Sites: Evidence from E-Citizens of Thailand," International Journal of Electronic Government Research (IJEGR) (5:1), pp. 19-35.

Williams, M.D., Rana, N.P., and Dwivedi, Y.K. 2015. "The Unified Theory of Acceptance and Use of Technology (Utaut): A Literature Review," Journal of Enterprise Information Management (28:3), pp. 443-488.

Yasar, J., and Giovanni, S. 2007. "Measuring Performance in the Public Sector: Challenges and Trends," Measuring Business Excellence (11:4), pp. 4-8. 


\section{Acknowledgements}

This research is supported by an Australian Government Research Training Program (RTP) Scholarship.

\section{Copyright}

Copyright: (C) 2018 Alvedi Sabani, Hepu Deng and Vinh Thai. This is an open-access article distributed under the terms of the Creative Commons Attribution-NonCommercial 3.0 Australia License, which permits non-commercial use, distribution, and reproduction in any medium, provided the original author and ACIS are credited. 